\title{
Formulasi dan Evaluasi Fisik Sediaan Gel Antiseptik Tangan Dari Ekstrak Etanol 96\% Daun Pandan Wangi (Pandanus Amaryllifolius Roxb)
}

\author{
Siti Marina, Banu Kuncoro, Sofi Nurmay Stiani, Rahmawida Putri* \\ Program Studi Farmasi, Sekolah Tinggi Farmasi Muhammadiyah Tangerang, Banten, Indonesia \\ Email: rahmawidaputri0@gmail.com
}

\begin{abstract}
Abstrak- Antiseptik berfungsi untuk membunuh atau menghambat pertumbuhan bakteri yang dapat menyebabkan timbulnya penyakit. Antseptik dapat diformulasikan dengan bahan alami sehingga ramah lingkungan. Pandan wangi merupakan tanaman yang sering dimanfaatkan daunnya sebagai bahan tambahan makanan, sebagai bahan pewarna hijau dan pemberi aroma. Pandan wangi juga merupakan salah satu tanaman yang dapat dijadikan bahan formulasi antiseptik karena memiliki aktivitas antibakteri dan dapat dijadikan sediaan topikal dalam bentuk gel. Tujuan penelitian ini untuk mengetahui perbedaan konsentrasi ekstrak daun pandan wangi (Pandanus amaryllifolius Roxb.) yang memiliki sifat fisik optimum. Penelitian ini merupakan penelitian eksperimental, metode maserasi digunakan untuk mendapatkan ekstrak etanol 96\% daun pandan wangi. Gel diformulasilan menjadi empat formula dengan konsentrasi ekstrak yaitu 10\%, 20\%, 30\%, dan 40\%. Uji evaluasi fisik meliputi : organoleptis, homogenitas, pH, daya sebar, viskositas, stabilitas, hedonik, iritasi dan pengujian antiseptik tangan. Hasil penelitian menunjukkan berbagai konsentrasi ekstrak tidak berpengaruh terhadap $\mathrm{pH}$ dan homogenitas. Kenaikan konsentrasi ekstrak berpengaruh terhadap perubahan warna dan aroma. Semakin tinggi konsentrasi ekstrak akan semakin pekat pula warnanya. Hasil pemeriksaan stabilitas sediaan menunjukkan bahwa ekstrak mengalami perubahan tekstur pada F2 dan perubahan aroma di F3. Formula sediaan gel yang baik berdasarkan mutu fisik dan uji hedonik adalah formula sediaan dengan konsentrasi $10 \%(\mathrm{~F} 1)$.
\end{abstract}

Kata Kunci: Pandanus amaryllifolius Roxb., Antiseptik tangan, Gel

\begin{abstract}
Antiseptic serves to kill or inhibit the growth of bacteria that can cause the onset of disease. Antiseptics can be formulated with natural ingredients so that they are environmentally friendly. Pandan wangi leaf is a plant that is often used as a food additive leaves, as a green dye and aroma. Pandan fragrance is also one of the plants that can be used as antiseptic formulations because it has antibacterial activity and can be used as a topical preparation in the form of gels. The aim of this research is to know the difference of pandan wangi leaf extract concentration (Pandanus amaryllifolius Roxb.) Which has optimum physical properties evaluation. This research is an experimental research, maseration method used to get extract with $96 \%$ ethanol. The gel was formulated into four formulas with various extract concentrations of $10 \%, 20 \%, 30 \%$, and $40 \%$. Evaluation tests include: organoleptic, homogeneity, $\mathrm{pH}$, dispersion, viscosity, stability, hedonic, irritation and hand antiseptic testing. The results showed that the concentration of extract had no effect on $\mathrm{pH}$ and homogeneity. Increased concentration of extract effect on the color change and aroma. The higher concentration of extract will be more concentrated also color. The result of stability inspection showed that texture change in F2 and aroma change in F3. A good gel preparation formula based on physical quality and hedonic test is a concentration formula of $10 \%(\mathrm{~F} 1)$.
\end{abstract}

Keywords: Pandanus Amaryllifolius Roxb., Hand Antiseptic, Gel.

\section{PENDAHULUAN}

Pemakaian antiseptik tangan dalam sediaan gel dikalangan masyarakat menegah keatas sudah menjadi gaya hidup. Beberapa sediaan paten antiseptik tangan dapat dijumpai di pasaran (Prabowo, dkk. 2018:525). Pandan wangi (Pandanus amaryllifolius Roxb.) merupakan tanaman yang sering dimanfaatkan daunnya sebagai bahan tambahan makanan, umumnya sebagai bahan pewarna hijau dan pemberi aroma. Aroma khas dari pandan wangi (Pandanus amaryllifolius Roxb.) diduga karena adanya senyawa turunan asam amino fenilalanin yaitu 2-acetyl-1-pyrroline (Faras et al.,2014:421). Kandungan senyawa metabolit pada daun pandan wangi (Pandanus amaryllifolius Roxb.) didapatkan senyawa alkaloid, flavonoid, saponin, tanin, steroid, glikosida dan triterpenoid. Kandungan metabolit ini berfungsi sebagai senyawa yang dapat menghambat pertumbuhan bakteri (Prameswari \& Widjanarko, 2013:17; Marina \& Astuti, 2012:87).

Kandungan metabolit tersebut memungkinkan dapat digunakan sebagai sediaan gel pembersih tanganMenurut penelitian Putri \& Azizah, 2019:93 bahwa pada ekstraksi dari pelarut etanol 96\% daun pandan wangi (Pandanus amaryllifolius Roxb.) dengan konsentrasi 20\% dapat menghambat pertumbuhan bakteri Escherichia coli. Tujuan Untuk mengetahui bagaimana pengaruh perbedaan konsentrasi ekstrak dalam formula sediaan gel antiseptik tangan ekstrak etanol 96\% daun pandan wangi terhadap sifat fisiknya, serta untuk mengetahui tingkat efektifitas antiseptik sediaan gel antiseptik tangan ekstrak daun pandan wangi dibandingkan dengan sediaan gel yang beredar dipasaran.

\section{METODOLOGI PENELITIAN}

\subsection{Alat dan Bahan}

\subsubsection{Alat}

Alat untuk membuat gel antiseptic antara lain timbangan analitik (Adam PW 254, England), aluminium foil, cawan porselen, Erlenmeyer (Pyrex, Japan), batang pengaduk, spatula, gelas ukur (Pyrex, Japan), gelas piala, mortir dan stamfer, pot gel, hot plate, pH meter Universal (Merck, Germany), kaca preparat, pipet tetes, autoklaf (Memmert, Japan), viskometer Brookfield (RV, USA), kertas saring, sudip, kapas swab. 


\title{
Journal of Pharmaceutical and Health Research
}

\author{
Vol 2, No 1, Februari 2021, pp. 21-27
}

ISSN 2721-0715 (media online)

DOI 10.47065/jharma.v2i1.837

\subsubsection{Bahan}

Bahan yang digunakan adalah Ekstrak Daun Pandan Wangi (Pandanus amaryllifolius Roxb), gliserin (Brataco), etanol 96\%, Na-CMC (Brataco), propilen glikol (Brataco), dan $\mathrm{NaCl}$ 0,9\%.

\subsection{Prosedur Penelitian}

\subsubsection{Determinasi Tumbuhan}

Determinasi dilakukan untuk memastikan kebenaran tanaman yang dipakai. Proses determinasi ini dilakukan di Herbarium Bogoriense, bidang Botani Pusat Penelitian dan Pengembangan Biologi (LIPI Cibinong) Jl. Raya Jakarta Bogor KM.46 Cibinong Bogor, 16911 Jawa Barat.

\subsubsection{Pembuatan Sampel}

Daun Pandan Wangi (Pandanus amaryllifolius Roxb) yang telah didapat kemudian dibersihkan dengan menggunakan air mengalir lalu dipotong kecil menggunakan alat pemotong dengan ukuran $\pm 1 \mathrm{~cm}$, kemudian dikeringkan dengan oven selama 3 hari pada suhu 500C sampai daun kering apabila di remas dengan tangan mudah hancur. Setelah itu, daun yang telah kering diserbukkan dengan menggunakan blender, diayak kemudian di timbang hingga menjadi simplia.

\subsubsection{Pembuatan Ekstrak}

Simplisia yang dihasilkan kemudian dimaserasi dengan cara merendam simplisia ke dalam pelarut etanol 96\%, kemudian disaring dengan menggunakan kertas saring dan ditampung dengan menggunakan Erlenmeyer. Residu/ampasnya kembali dimaserasi lagi dengan cara yang sama sampai pelarutnya jernih dinamakan proses remaserasi (Sentat, 2016). Ekstrak maserasi/filtrat yang dihasilkan ditampung menjadi satu dan diuapkan dengan menggunakan rotary evavorator pada suhu $50^{\circ} \mathrm{C}$ sampai pelarut habis menguap, sehingga dihasilkan ekstrak kental daun pandan wangi.

\subsubsection{Tahapan Pembuatan Gel}

Cara pembuatan yakni semua bahan yang digunakan ditimbang terlebih dahulu sesuai dengan formulasi. Pembuatan gel antiseptik tangan dari ekstak daun pandan wangi (Pandanus amaryllifolius Roxb) 10\% dilakukan dengan cara Na-CMC sebanyak 3 gr, dikembangkan dicawan porselen dengan sedikit aquadest panas, kemudian dilakukan pengadukan secara terus-menerus sehingga terdispersi sempurna dan terbentuk berbasis gel.. Selanjutnya, ditambahkan gliserin 5 gr, propilenglikol $15 \mathrm{gr}$, dan sisa aquadest hingga bobot gel menjadi 67 gr dengan cara terus dilakukan pengadukan hingga terbentuk gel dan ditambahkan ekstrak etanol daun pandan wangi konsentrasi 10\%. Untuk pembuatan 20\%, 30\%, dan $40 \%$ dilakukan dengan cara yang sama dengan pembuatan gel antiseptik tangan ekstrak daun pandan wangi. Setelah itu, ketiga formulasi gel disimpan pada tempat yang gelap dan dingin selama semalaman.

\subsubsection{Formulasi Gel}

Formulasi yang digunakan dalam pembuatan gel antiseptic ekstrak etanol $96 \%$ daun pandan wangi (Pandanus amaryllifolius Roxb) dapat dilihat pada tabel 1 berikut.

Tabel 1. Formulasi Gel Antiseptik

\begin{tabular}{llccccc}
\hline No & \multicolumn{1}{c}{ Bahan } & \multicolumn{4}{c}{ Formulasi Sediaan Gel Antiseptik } & Fungsi \\
& & $\mathrm{F} 1$ & $\mathrm{~F} 2$ & $\mathrm{~F} 3(30 \%)$ & $\mathrm{F} 4(40 \%)$ & \\
& & $(10 \%)$ & $(20 \%)$ & & & \\
\hline 1 & Ekstrak etanol 96\% daun & $10 \mathrm{~g}$ & $20 \mathrm{~g}$ & $30 \mathrm{~g}$ & $40 \mathrm{~g}$ & Zat Aktif \\
& pandan wangi & & & & & \\
2 & Na-CMC & $3 \mathrm{~g}$ & $3 \mathrm{~g}$ & $3 \mathrm{~g}$ & $3 \mathrm{~g}$ & Basis gel \\
3 & Gliserin & $5 \mathrm{~g}$ & $5 \mathrm{~g}$ & $5 \mathrm{~g}$ & $5 \mathrm{~g}$ & Humektan \\
4 & Proplilen glikol & $15 \mathrm{~g}$ & $15 \mathrm{~g}$ & $15 \mathrm{~g}$ & $15 \mathrm{~g}$ & Humektan \\
5 & Purified water & add 100 & add 100 & add 100 & add 100 & Pelarut \\
\hline
\end{tabular}

\subsubsection{Evaluasi Sediaan Gel}

Evaluasi yang dilakukan dalam penelitian ini meliputi: Organoleptik, homogenitas, stabilitas, viskositas, daya sebar, $\mathrm{pH}$, iritasi, hedonik, dan tingkat efektifitas antiseptik.

\subsubsection{Analisis Data}

Data yang diperoleh dalam penelitian ini dianalisis menggunakan analisis deskriptif dimana dengan menggunakan metode deskriptif ini dapat menggambarkan suatu keadaan yang objektif, data dapat di sajikan dalam. 
Journal of Pharmaceutical and Health Research

Vol 2, No 1, Februari 2021, pp. 21-27

ISSN 2721-0715 (media online)

DOI 10.47065/jharma.v2i1.837

\section{HASIL DAN PEMBAHASAN}

\section{Determinasi Tumbuhan}

Hasil determinasi menunjukan bahwa tanaman yang digunakan untuk penelitian memiliki nama ilmiah Pandanus amaryllifolius Roxb.

\subsection{Skrining Fitokimia}

Skrining fitokimia dilakukan untuk mengetahui kandungan metabolit sekunder dari suatu tumbuhan atau ekstrak. Hasil skrining fitokimia ekstrak etanol 96\% daun pandan wangi (Pandanus amaryllifolius Roxb) dapat dilihat pada tabel 2.

Tabel 2. Hasil Skrining Fitokimia

\begin{tabular}{ccc}
\hline No & Parameter Uji & Hasil Pengujian \\
\hline 1 & Alkaloid & + \\
2 & Flavonoid & + \\
3 & Tanin & + \\
4 & saponin & + \\
\hline
\end{tabular}

Berdasarkan hasil skrining fitokimia ekstrak etanol 96\% daun pandan wangi (Pandanus amaryllifolius Roxb) yang terdapat pada Tabel 2. menunjukan bahwa ekstrak etanol 96\% daun pandan wangi mengandung senyawa alkaloid, flavonoid, tanin, dan saponin yang berfungsi sebagai zat aktif yang memiliki aktivitas antibakteri (Ismiyati \& Mardiyaningsih, 2015). Pembuatan gel antiseptik dari ekstrak etanol 96\% daun pandan wangi menggunakan CMC-Na sebagai basis gel. Propilenglikol digunakan sebagai humektan yang akan menjaga kestabilan sediaan dengan cara mengabsorbsi lembab dari lingkungan dan mengurangi penguapan air dar sediaan. Selain menjaga kestabilan, secara tidak langsung juga dapat mempertahankan kelembaban kulit sehingga kulit tidak kering (Pratiwi, dkk. 2018). Gliserin juga berfungsi sebagai humektan atau penahan lembab yang dapat meningkatkan daya sebar sediaan dan melindungi sediaan dari kemungkinan menjadi kering. Dan purified water berfungsi pelarut dalam formulasi sediaan gel (Stiani, 2018).

\subsection{Hasil Ekstraksi}

Metode ekstraksi yang digunakan adalah metode maserasi dengan etanol 96\% sebagai pelarut untuk menghasilkan ekstrak yang kental (murni) sehingga mempermudah untuk proses identifikasi. Pemilihan proses maserasi sebagai metode ekstraksi dikarenakan maserasi menggunakan peralatan yang sederhana serta proses pengerjaannya cukup mudah. Sebanyak $5 \mathrm{~kg}$ simplisia dimaserasi hingga menggunakan rotary evavorator untuk memastikan seluruh pelarut telah menguap sehingga didapatkan ekstrak kental yang sebanyak 439,7 gram dan diperoleh rendemen ekstrak sebesar 8,794\%.

\subsection{Evaluasi Sediaan Gel Antiseptik}

\section{Uji Organoleptik}

Uji organoleptik dimaksudkan untuk melihat tampilan fisik suatu sediaan yang meliputi bentuk, warna dan aroma. Sediaan gel antiseptik ekstrak etanol 96\% daun pandan wangi (Pandanus amaryllifolius Roxb) yang telah selesai disimpan dan dilakukan pengamatan bentuk, warna dan aroma selama 4 minggu dengan interval pengamatan sekali seminggu.

Tabel 3. Hasil Uji Organoleptik

\begin{tabular}{clll}
\hline \multirow{2}{*}{ Formula } & \multicolumn{3}{c}{ Organoleptis } \\
\cline { 2 - 4 } & \multicolumn{1}{c}{ Bentuk } & \multicolumn{1}{c}{ Aroma } & \multicolumn{1}{c}{ Kode warna } \\
\hline F1 & Semi padat & Khas Ekstrak & Pantone 371 C \\
F2 & Semi padat & Khas Ekstrak & Pantone 2018 CP \\
F3 & Semi padat & Khas Ekstrak & Pantone 3995 C \\
F4 & Semi padat & Khas Ekstrak & Pantone 5743 C \\
\hline
\end{tabular}

Berdasarkan hasil pada Tabel 3 diatas, hasil pengujian organoleptis dapat di ketahui hasil formulasi sediaan gel dengan berbagai konsentrasi ekstrak. Pada sediaan gel dengan konsentrasi ekstrak 10\% memiliki warna hijau tua, konsentrasi ekstrak 20\% memiliki warna orange (pada formula ke-2 memiliki warna orange dikarenakan kesalahan pengambilan ekstrak. Ekstrak yang telah disimpan dalam lemari es mengalami endapan pada bagian bawah ekstrak kental dan pada bagian atas ekstrak air lalu untuk diformulasikan gel, ekstrak tidakdikocok terlebih dahulu dan ditimbanglah ekstrak pada bagian atas yaitu ekstrak air). Konsentrasi ekstrak 30\% memiliki warna hijau tua agak kecoklatan, dan konsetrasi $40 \%$ memiliki warna hijau tua pekat. Dengan aroma yang khas dan memiliki perbedaan bentuk. Maka dapat disimpulkan bahwa peningkatan kadar konsentrasi ekstrak pada sediaan gel akan berpengaruh pada organoleptis dari sediaan tersebut terutama intensitas warna.

\section{Uji Homogenitas}




\section{Journal of Pharmaceutical and Health Research}

Vol 2, No 1, Februari 2021, pp. 21-27

ISSN 2721-0715 (media online)

DOI 10.47065/jharma.v2i1.837

Pengujian homogenitas dilakukan untuk melihat apakah bahan yang digunakan dalam pembuatan sudah tercampur sempurna atau belum. Homogenitas pada sediaan berpengaruh pada penyebaran masker gel dikulit. Sediaan gel antiseptik ekstrak etanol $96 \%$ daun pandan wangi harus memiliki massa yang homogen. Tidak boleh ada bahan padat yang masih menggumpal pada saat dioleskan karna akan berpengaruh pada zat aktif yang diserap. Pengamatan dilakukan selama 4 minggu dengan interval sekali seminggu. Hasil uji homogenitas dapat dilihat pada tabel 4.

Tabel 4. Hasil Uji Homogenitas

\begin{tabular}{ccccc}
\hline Formula & \multicolumn{4}{c}{$\begin{array}{c}\text { Waktu Penyimpanan } \\
\text { Minggu Ke- }\end{array}$} \\
\cline { 2 - 5 } & $\mathbf{1}$ & $\mathbf{2}$ & $\mathbf{3}$ & $\mathbf{4}$ \\
F0 & Homogen & Homogen & Homogen & Homogen \\
FI & Homogen & Homogen & Homogen & Homogen \\
FII & Homogen & Homogen & Homogen & Homogen \\
FIII & Homogen & Homogen & Homogen & Homogen \\
Kontrol positif & Homogen & Homogen & Homogen & Homogen \\
\hline
\end{tabular}

Berdasarkan tabel 4. dapat dilihat hasil pengamatan uji homegenitas pada ke 4 formula sediaan gel antiseptik yang dihasilkan memiliki sifat homogenitas yang baik dan tidak terlihat adanya perubahan pada saat uji homogenitas yang dilakukan menggunakan object glass. Pengujian dilakukan dengan cara mengoleskan sediaan di atas object glass dan ditutup dengan kaca penutup. Setelah dilakukan pengujian maka didapatkan sediaan yang homogen dan tetap labil dalam masa penyimpanan 4 minggu. Hal ini terlihat dengan tidak adanya butir - butir kasar saat dioleskan pada object glass saat dilakukan pemeriksaan pada sediaan gel saat pengamatan mulai pada minggu ke-0 (sesaat setelah sediaan selesai dibuat) sampai minggu ke-4. Hal ini berarti semua formula yang dihasilkan memenuhi persyaratan.

\section{Uji Viskositas}

Uji viskositas bertujuan untuk mengetahui konsistensi sediaan, yang berpengaruh dan penggunaan obat secara topikal. Pengukuran viskositas sediaan dilakukan menggunakan Viskometer Lamy Rheology spindle L No 4, durasi 20 detik dengan kecepatan 50 rpm. Hasil uji viskositas dapat dilihat pada tabel 5.

Tabel 5. Hasil Uji Viskositas

\begin{tabular}{ccccc}
\hline \multirow{2}{*}{ Formula } & \multicolumn{4}{c}{ Pengujian viskositas minggu ke- : } \\
\cline { 2 - 5 } & 1 & 2 & 3 & 4 \\
\hline Kontrol Positif & $6250 \mathrm{cps}$ & $7220 \mathrm{cps}$ & $6590 \mathrm{cps}$ & $6390 \mathrm{cps}$ \\
F1 & $3300 \mathrm{cps}$ & $3480 \mathrm{cps}$ & $3880 \mathrm{cps}$ & $3010 \mathrm{cps}$ \\
F2 & $2590 \mathrm{cps}$ & $2540 \mathrm{cps}$ & $2590 \mathrm{cps}$ & $2440 \mathrm{cps}$ \\
F3 & $4560 \mathrm{cps}$ & $4540 \mathrm{cps}$ & $4500 \mathrm{cps}$ & $4240 \mathrm{cps}$ \\
F4 & $5070 \mathrm{cps}$ & $4920 \mathrm{cps}$ & $4850 \mathrm{cps}$ & $4480 \mathrm{cps}$ \\
\hline
\end{tabular}

Berdasarkan tabel 5. dapat dilihat Hasil pengamatan viskositas sediaan gel antiseptik tangan pada pengujian minggu ke-1 (mengalami peningkatan), minggu ke-2 (lebih meningkat), minggu ke-3 dan k-4 mengalami penurunan. Tetapi penurunanya tidak besar, hal ini dikarenakan faktor Na-CMC sebagai basis gel yang digunakan menghasilkan sediaan gel yang akan mengalami penurunan nilai viskositas dan pada saat penyimpanan. Kemasan yang kurang kedap juga dapat menyebabkan gel menyerap uap air dari luar, sehingga menambah volume air dalam gel (Panjaitan dkk., 2012)

4. $\mathrm{Uji} \mathrm{pH}$

Uji pH merupakan parameter fisikokimia yang dilakukan pada pengujian sediaan topikal, yang bertujuan untuk mengetahui keamanan sediaan saat digunakan agar tidak mengiritasi kulit. Sediaan topikal sebaiknya memiliki pH yang sama dengan pH Balance kulit yaitu 4,5 - 6,5. Pengujian dilakukan selama 4 minggu dengan interval pengujian sekali seminggu. Hasil uji pH dapat dilihat pada tabel 6.

Tabel 6. Hasil Uji pH

\begin{tabular}{ccccc}
\hline Formula & \multicolumn{4}{c}{$\begin{array}{c}\text { Pengujian } \mathrm{pH} \\
\text { Minggu Ke- }\end{array}$} \\
\cline { 2 - 5 } & $\mathbf{1}$ & $\mathbf{2}$ & $\mathbf{3}$ & $\mathbf{4}$ \\
\hline FI & 5,1 & 4,8 & 4,9 & 4,5 \\
FII & 4,7 & 4,9 & 4,6 & 4,6 \\
FIII & 4,9 & 4,6 & 4,7 & 4,6 \\
FIV & 4,5 & 4,7 & 4,6 & 4,5 \\
Kontrol positif & 5,4 & 6,3 & 6,3 & 6,4 \\
\hline
\end{tabular}




\section{Journal of Pharmaceutical and Health Research}

Vol 2, No 1, Februari 2021, pp. 21-27

ISSN 2721-0715 (media online)

DOI 10.47065/jharma.v2i1.837

Berdasarkan hasil uji pH pada tabel 6. hasil pengujian $\mathrm{pH}$ gel antiseptik pada keempat formula dan kontrol positif daun pandan wangi masih memenuhi syarat $\mathrm{pH}$ kulit yaitu 4,5 - 6,5 sehingga tidak menyebabkan iritasi.

\section{Uji Daya Sebar}

Menurut Adnan (2017:43) bahwa pengujian daya sebar gel antiseptik dimaksudkan umtuk mengetahui seberapa gel antiseptik dapat menyebar pada kulit. Hasil uji daya sebar dapat dilihat pada Gambar 1.

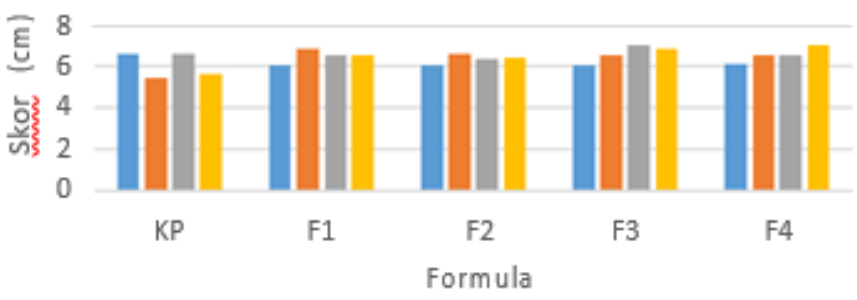

m minggu ke-1 m minggu,ke-2 m minggu ke-3 m mingguke-4

Gambar 1. Uji daya Sebar

Berdasarkan data pada Gambar.1 ekstrak etanol 96\% daun pandan wangi nilai daya sebar gel antiseptik tangan dengan beberapa formula terjadi perubahan meningkat dan menurun disetiap minggunya. Daya sebar ini berhubungan terbalik dengan kekentalan sediaan gel. Hal ini dibuktikan dengan nilai viskositas gel yang semakin menurun selama empat minggu penyimpanan akan mempengaruhi nilai daya sebar gel yang semakin membesar. Dan nilai viskositas gel yang semakin meningkat selama empat penyimpanan akan mempengaruhi nilai daya sebar gel yang semakin membesar. Dan nilai viskositas gel yang semakin meningkat selama empat minggu penyimpanan akan mempengaruhi nilai daya sebar gel yang semakin menurun

\section{Uji Iritasi Gel}

Uji iritasi dilakukan untuk melihat apakah gel yang dibuat dapat mengiritasi kulit atau tidak. Uji ini dilakukan terhadap 10 responden. Reaksi iritasi positif ditandai oleh adanya kemerahan, gatal-gatal, atau bengkak pada kulit tangan yang diberi perlakuan (Sidiq \& Apriliyanti, 2018:134). Hasil uji iritasi dapat dilihat pada Tabel 7.

Tabel 7. Hasil Uji Iritasi

\begin{tabular}{lllllllllllll}
\hline Pengamatan & Formula & \multicolumn{1}{c}{ Sukarelawan } \\
& & 1 & 2 & 3 & 4 & 5 & 6 & 7 & 8 & 9 & 10 \\
\hline \multirow{3}{*}{ Merah } & FI & - & - & - & - & - & - & - & - & - & - \\
& FII & - & - & - & - & - & - & - & - & - & - \\
& FIII & - & - & - & - & - & - & - & - & - & - \\
& FIV & - & - & - & - & - & - & - & - & - & - \\
\cline { 2 - 6 } Gatal & FI & - & - & - & - & - & - & - & - & - & - \\
& FII & - & - & - & - & - & - & - & - & - & - \\
& FIII & - & - & - & - & - & - & - & - & - & - \\
& FIV & - & - & - & - & - & - & - & - & - & - \\
Bengkak & FI & - & - & - & - & - & - & - & - & - & - \\
& FII & - & - & - & - & - & - & - & - & - & - \\
& FIII & - & - & - & - & - & - & - & - & - & - \\
& FIV & - & - & - & - & - & - & - & - & - & -
\end{tabular}

Berdasarkan tabel 7. hasil uji iritasi terhadap 10 responden menunjukkan keempat gel antiseptik tidak menimbulkan tanda-tanda iritasi seperti timbulnya kemerahan pada kulit, gatal, bengkak, rasa sakit, maupun terluka.

7. Uji Hedonik Gel

Berdasarkan hasil data penilaian panelis bahwa F1 dengan aroma skalanya 3 (cukup suka), warna dengan skalanya 2 (tidak suka), dan tekstur dengan skalanya 4 (suka). Kemudian pada F2 dengan aroma skalanya 2 (tidak suka), warna dengan skalanya 4 (suka), dan tekstur dengan skalanya 4 (suka). Pada F3 dengan aroma skalanya 1 (sangat tidak suka), warna dengan skalanya 2 (tidak suka), dan tekstur dengan skalanya 3 (cukup suka). Kemudian pada F4 dengan aroma skalanya 2 (tidak suka), warna dengan skalanya 2 (tidak suka), serta tekstur mendapatkan skala 3 (cukup suka). Untuk kontrol positif rata-rata hanya menyukai pada parameter warna dan aromanya saja. 


\title{
Journal of Pharmaceutical and Health Research
}

\author{
Vol 2, No 1, Februari 2021, pp. 21-27
}

ISSN 2721-0715 (media online)

DOI 10.47065/jharma.v2i1.837

\section{Uji Antiseptik Gel}

Uji antiseptik gel yang dilakukan adalah dengan metode replika sebelum dan sesudah pemakaian gel antiseptik. Tujuan dari pengujian ini adalah untuk mengetahui efektifitas daya antiseptik yang dihasilkan dari gel antiseptik sebelum dan sesudah penggunaan.

Tabel 8. Hasil Uji Antiseptik Gel

\begin{tabular}{lcccc}
\hline \multicolumn{1}{c}{ Formula } & \multicolumn{4}{c}{ Replikasi Replikasi } \\
& 1 & 2 & 3 & Replikasi \\
& rata \\
& 0 & 1 & 1 & 0,667 \\
\hline Formula 1 (10\%) & 0 & 0 & 0 & 0 \\
Formula 2 (20\%) & 0 & 1 & 0 & 0,333 \\
Formula 3 (30\%) & 0 & 1 & 1 & 1 \\
Formula 4 (40\%) & 1 & 3 & 3 & 3 \\
Kontrol Positif (X) & 3 & 4 & 4 & 4 \\
Kontrol negatif & 4 & 4 & \\
\hline
\end{tabular}

Berdasarkan tabel 8 hasil uji antiseptic gel tangan pada keempat formula dengan tiga proses pengulangan (replikasi) didapatlah rata-rata formula berturut-turut, $\mathrm{F} 1=0,067, \mathrm{~F} 2=0, \mathrm{~F} 3=0,333, \mathrm{~F} 4=1$. Dan rata-rata untuk kontrol positif 3 serta rata-rata untuk kontrol negative sebesar 4.

\subsection{Analisis Data}

Analisis data dilakukan dengan menggunakan SPSS 24 pada uji viskositas dengan hasil uji One Way Anova pengamatan viskositas pada keempat formula menggunakan uji Kolmogorov-Smirnov untuk mengetahui data hasil Output di atas menunjukkan bahwa data berdistribusi normal. Hal ini dapat dilihat dari nilai asymp.sig (2-tailed) sebesar $0.200>0.05$, sehingga nilai signifikan yang didapat >0,05 sehingga dapat disimpulkan bahwa data terdistribusi normal.

Setelah pengujian normalitas kemudian dilakukan pengujian homogenitas varian data untuk mengetahui data yang dimiliki homogen atau tidak. Untuk hasil uji homogenitas varian data dari hasil viskositas sediaan Gel antiseptik tangan ekstrak etanol 96\%, didapatkan nilai signifikan $(\mathrm{p}=0,339)$ lebih besar dari 0,05 . Berdasarkan hasil yang diperoleh nilai signifikansi $0,000<0,05$ maka hipotesis diatas ditolak, yang berarti "terdapat perberdaan perubahan viskositas setiap minggunya".

Analisis data selanjutnya dilakukan pada uji pH terlihat bahwa pengujian $\mathrm{pH}$ hasil analisa uji One Way Anova pengamatan $\mathrm{pH}$ pada keempat formula dengan menggunakan uji Kolmogrov-Smirnov untuk mengetahui data hasil pengukuran menunjukkan bahwa data berdistribusi normal dengan normalitas 24. Hal ini dapat dilihat dari nilai asymp.sig (2-tailed) sebesar $0.01<0.05$, nilai signifikan yang didapat $<0,05$ sehingga dapat disimpulkan bahwa data terdistribusi tidak normal.

Setelah pengujian normalitas kemudian dilakukan pengujian homogenitas varian data untuk mengetahui data yang dimiliki homogen atau tidak. Untuk hasil uji homogenitas varian data dari hasil $\mathrm{pH}$ sediaan Gel antiseptik tangan ekstrak etanol DPW, didapatkan nilai signifikan $(\mathrm{p}=0,016)$ maka lebih kecil dari 0,05 . Hal ini menunjukkan bahwa varian data tidak homogen maka harus dilanjutkan dengan Kruskall Wallis terlebih dahulu.Tes Kruskal Wallis dilakukan karena nilai homogenitasdari penelitian ini tidak mencapai lebih dari 0,05. Hasil uji Kruskal Wallis nilai Chi-square adalah 18,596 dengan Asymp Sig. pada 0,02 atau lebih kecil dari 0,05 sehingga diputuskan ada perubahan $\mathrm{pH}$ disetiap minggunya. Berdasarkan hasil analisis Anova diperoleh nilai signifikansi $0,000<0,05$ maka hipotesis diatas ditolak, yang berati "terdapat perberdaan perubahan $\mathrm{pH}$ disetiap minggunya".

Analisis data juga dilakukan pada uji sediaan gel dengan menggunakan SPSS 24 ditemukan jumlah koloni yang didapat kemudian dianalisa menggunakan statistik One Way Anova terlihat bahwa hasil uji Kolmogrof-Smirnof digunakan untuk memeriksa kesesuaian antara nila-nilai sampel dan suatu distribusi teoritis. Dari pengujian non-parametric test dengan uji kolmogorov-Smirnorv akan didapatkan hasil normalitas data dengan kriteria data dikatakan normal jika nilai $\mathrm{N}>0,05$. Normalitas data dari uji Kolmogorov-Smirnorv uji efektivitas antibakteri ekstrak etanol $96 \%$ untuk mengetahui data hasil pengukuran menunjukkan bahwa data berdistribusi normal dengan normalitas 18 . Hal ini dapat dilihat dari nilai asymp.sig (2-tailed) sebesar $0.01<0.05$, nilai signifikan yang didapat $<0,05$ sehingga dapat disimpulkan bahwa data terdistribusi tidak normal.

Setelah pengujian normalitas kemudian dilakukan pengujian homogenitas varian data untuk mengetahui data yang dimiliki homogen atau tidak. Untuk hasil uji homogenitas varian data dari hasil uji antibakteri sediaan Gel antiseptik tangan ekstrak etanol $96 \%$, didapatkan nilai signifikan $(\mathrm{p}=0,000)$ lebih kecil dari 0,05 hal ini menunjukkan bahwa varian data tidak homogen kemudian harus dilanjutkan pengujian kruskal wallis terlebih dahulu. Tes kruskal wallis dilakukan karena nilai homogenitas pada penelitian ini tidak mencapai lebih dari 0,05. Hasil uji Kruskal Wallis nilai Chi-square adalah 15,168 dengan Asymp Sig. pada 0,010 atau lebih kecil dari 0,05 sehingga diputuskan ada perbedaan perubahan dari hasil pengujian.

Hasil analisis ANOVA LSD menunjukkan bahwa konsentrasi 10\%, 20\%, 30\% dan 40\% tidak memiliki perbedaan bermakna dengan kontrol positif. Hal ini menunjukkan konsentrasi 10\%, 20\%, 30\% dan 40\% memiliki tingkat efektifitas yang sama dengan kontrol positif (sediaan X). 


\title{
Journal of Pharmaceutical and Health Research
}

\author{
Vol 2, No 1, Februari 2021, pp. 21-27
}

ISSN 2721-0715 (media online)

DOI 10.47065/jharma.v2i1.837

\section{KESIMPULAN}

Berdasarkan hasil penelitian dapat disimpulkan bahwa berdasarkan hasil penelitian menunjukkan bahwa perbedaan konsentrasi ekstrak etanol 96\% daun pandan wangi (Pandanus amaryllifolius Roxb) dalam formula sediaan berbeda secara signifikan terhadap sifat fisik, viskositas (Sig. 0,000) dan pH (Sig.0,000). Dan daya antiseptik sediaan gel antiseptik tangan ekstrak daun pandan wangi (Pandanus amaryllifolius Roxb) dengan berbagai konsentrasi memiliki tingkat efektifitas antiseptik yang sama dengan sediaan gel yang beredar di pasaran.

\section{DAFTAR PUSTAKA}

Adnan, J. (2017). Formulasi gel ekstrak daun beluntas (PluceaindicaLess) dengan Na-CMC sebagai basis gel. Journal of Pharmaceutical Science and Herbal Technology, 1(1), 41-44.

Astuti, D. P., Husni, P., \& Hartono, K. (2017). Formulasi dan uji stabilitas fisik sediaan gel antiseptik tangan minyak atsiri bunga lavender (Lavandula angustifolia Miller). Farmaka, 15(1), 176-184.

Faras, A.F., Wadkar, S.S., and Ghosh, J.S. (2014). Effect of Leaf Extract of Pandanus amaryllifolius Roxb on Growth of Escherichia coli and Micrococcus (Staphylococcus) aureus, International Food Research Journal 21(1):421-423.

Ismiyati, N., \& Mardiyaningsing, A. (2015). Aktivitas Sitotoksik Ekstrak Etanolik dan Fraksi dari Ekstrak Etanolik Daun Pandan (Pandanus amaryllifolius roxb) Terhadap Sel Kanker Payudara MCF-7. In Prosiding Seminar Nasional \& Internasional.

Marina, R., \& Astuti, E. P. (2012). Potensi Daun Pandan (Pandanus Amaryllifolius) Dan Mangkokan (Notophanax Scutellarium) Sebagai Repelen Nyamuk Aedes Albopictus. ASPIRATOR-Journal of Vector-borne Disease Studies, 4(2), 85-91.

Panjaitan, E.N., Saragih, A., Purba, D. (2012). Formulasi Gel dari Ekstrak Rimpang Jahe Merah (Zingiber officinale Roscoe), Journal of Pharmaceutics and Pharmacology, 2012 Vol (1), Hal 9-20

Prabowo, W. C., Widayat, W., \& Defriana, S. (2018). Formulasi Infusan Daun Sirih Merah (Piper crocatum) Sebagai Gel Antiseptik Tangan. Jurnal Sains Dan Kesehatan, 1(10), 525-530.

Prameswari, O. M., \& Widjanarko, S. B. (2013). Uji Efek Ekstrak Air Daun Pandan Wangi Terhadap Penurunan Kadar Glukosa Darah Dan Histopatologi Tikus Diabetes Mellitus [In Press 2014]. Jurnal Pangan dan agroindustri, 2(2), 16-27.

Pratiwi, F. A., Amal, S., \& Susilowati, F. (2018). Variasi Jenis Humektan Pada Formulasi Sediaan Masker Gel Peel Off Ekstrak Kulit Buah Pisang Kepok (Musa paradisiaca pericarpium). Pharmaceutical Journal of Islamic Pharmacy, 2(2), 31-36.

Putri, D. A., \& Azizah, M. (2019). Uji Aktivitas Anti Bakteri Ekstrak Etanol Daun Pandan Wangi (Pandanus amaryllifolius roxb) Terhadap Bakteri Penyebab Diare. Jurnal Kesehatan Saelmakers PERDANA (JKSP), 2(1), 91-98.

Sentat, T. (2016). Uji Aktivitas Anti Inflamasi Ekstrak Etanol Daun Pandan Wangi (Pandanus Amaryllifolius Roxb.) Pada Mencit Putih Jantan (Mus Musculus). In Seminar Nasional 2016 Akademi Farmasi Samarinda.

Sidiq, H. B. H. F., \& Apriliyanti, I. P. (2018). Evaluasi EVALUASI SIFAT FISIK DAN UJI IRITASI GEL EKSTRAK KULIT BUAH PISANG (Musa acuminata Colla). JCPS (Journal of Current Pharmaceutical Sciences), 2(1), 131-135.

Stiani, S. N., Sari, S. P., \& Kuncoro, B. (2018). Formulasi Dan Evaluasi Sediaan Gel Ekstrak Etanol 96\% Daun Pandan Wangi (Pandanus amaryllifolius Roxb.) Sebagai Sediaan Antinyamuk Aedes aegypti. Jurnal Farmagazine, 5(2), 39-46. 